\title{
Drought assessment using the reconnaissance drought index (RDI): A case study of Eastern Mediterranean, Seyhan, Ceyhan, and Asi basins of Turkey
}

\author{
Emre Topçu* and Neslihan Seçkin** \\ * Department of Civil Engineering, Kafkas University, Kars, 36100, Turkey. \\ ** Department of Civil Engineering, Çukurova University, Adana, 01330, Turkey. \\ * Corresponding Author: emretopcu01@gmail.com
}

Submitted :02/11/2020

Revised : 29/04/2021

Accepted : 17/05/2021

\begin{abstract}
In this study, drought analysis was carried out in the region, which includes the Eastern Mediterranean, Seyhan, Ceyhan, and Asi basins located in the south of Turkey. In total, data from 35 meteorological stations has been analyzed. As a drought index, the Reconnaissance Drought Index (RDI) was utilized. The Thornthwaite method was selected in the calculation of Potential Evapotranspiration (PET). According to the results, the PET values of all stations have increased in recent years. 3-, 6-, 9-, and 12-month RDI values have been plotted based on the hydrological years. As stated by RDI results, there was mild drought in the basin. The drought results obtained by Turkish State Meteorological Service (The Ministry of Agriculture and Forestry General Directorate of Meteorology) with the Standardized Precipitation Index (SPI) method were compared with the results in this study. In this study, drought mapping for RDI was carried out using the annual values of stations with common observation years to monitor visually spatial spread of the drought.
\end{abstract}

Keywords: Drought; Reconnaissance drought index; Precipitation; Evapotranspiration.

\section{INTRODUCTION}

Drought is a life-threatening climatic disaster for people about $65 \%$ of their bodies are water and all vital events in the world. The drought does not have a precise definition as it is not fully understood. Drought is defined according to different hydrometeorological parameters, socioeconomic factors and different water demands in different geographical regions. Definitions are mostly regional. The drought definition for any region may not reflect the drought status of another region. In particular, the temperature difference between the two regions can make a difference in terms of drought, even if they receive the same precipitation. Nevertheless, drought can still be defined as "statistically periodic precipitation and soil moisture deficiency in a region." The absence of precipitation in an area does not indicate that there is drought in that area. For the start of drought from a climatological point of view, from the rainfall-free period, the climate of that region must have been without precipitation over a long period of 
time. Drought is a recurring climate event. It can occur anywhere in the world and in any season. Compared to other natural disasters, drought occurs much slower and lasts much longer. It is very difficult to predict how long it will last, its severity, and where it will occur (Mishra and Singh, 2010). Generally, drought is examined in 4 categories, that is, meteorological, agricultural, hydrological and socioeconomic drought (Wilhite and Glantz, 1985; Agnew, 1990; Agnew and Warren 1996; AMS, 2004; Vangelis et al. 2013; Anl1, 2014). Soil moisture conditions respond to precipitation abnormalities in a relatively short period of time, while groundwater, river, and reservoir storage respond to precipitation abnormalities in long-term precipitation. Although the exact limits are not clear, it is proposed to examine drought values from 1 to 2 months for meteorological analysis, 1 to 6 months for agricultural drought analysis and 6 to 24 months for hydrological drought analysis and applications (WMO, 2012).

Drought has a negative effect on existential events such as economy, energy, recreation, agriculture, water resources, ecosystem and human health (Riebsame et al., 1991). The Reconnaissance Drought Index (RDI) is a new meteorological drought index, which can be directly compared with the widely used Standardized Precipitation Index (SPI) (Mckee et al., 1993) but better represents water balance conditions (Tsakiris and Vangelis, 2005). This new drought index uses potential evapotranspiration data in addition to precipitation. Pashiardis and Michaelides (2008), in their study, calculated the drought intensity, duration, and spatial spread using the data they obtained from the precipitation stations located in the entire island of Cyprus. They utilized RDI and SPI as a method. Yurekli et al., (2010), in their study, tried to detect the

drought of Karaman province in Turkey using SPI, RDI, and Effective Drought Index (EDI). According to the RDI, mild drought and moderate drought were observed in Karaman. Zarch et al. (2011), in their study, used the data they obtained from 40 meteorological synoptic stations in Iran to investigate the drought in the region by using SPI and RDI. They conducted their research in 3-, 6-, 9-, 12-, 18-, and 24-month periods. They reported that RDI is worth using for drought analysis in the region as it included evapotranspiration and water loss. Vangelis et al. (2013) examined whether the potential evapotranspiration calculation method had an effect on the index values when calculating the RDI. They used Hargreaves, Thornthwaite, Blaney-Criddle, and FAO Penman-Monteith methods. As a result, they noted that the potential evapotranspiration method did not make a significant difference in the calculation of RDI. Zehtabian et al. (2013) used precipitation data obtained from 6 synoptic stations in Khorasan region in Iran. They calculated the potential evapotranspiration using Thornthwaite method, using annual temperature and precipitation values for RDI. Anl (2014), in his study, conducted a temporal change of reference plant water consumption in Southeastern Anatolia Region and meteorological drought analysis with RDI method. With the RDI method applied to predict

meteorological drought in the provinces, the region generally dominated by mild drought, but moderate and severe drought also occurred. Zarch et al. (2015) examined the data they obtained from more than 4000 meteorological stations worldwide for global climate change between 1960 and 2009. RDI and SPI were used as a method. Malachiya and Suryanarayana (2016) calculated the index of 3-, 6-, 9-, and 12-month periods with RDI using 35 years (1965-2000) precipitation and potential evapotranspiration values in Amreli region in India. They compared SPI with RDI trend analysis. Agha and Şarlak (2017), in their paper, analyzed the drought in the region by using the data of 10 meteorological stations in Iraq between 1980 and 2011. They utilized the Penman-Monteith method for potential evapotranspiration calculation. Mohammed and Scholz (2017) stated that RDI was a strong index for meteorological drought due to the fact that RDI included precipitation and evaporation. They reported that both standardized and normalized RDI were determined by potential evapotranspiration methods at various climatic conditions. Besides RDI, drought studies such as (Hınıs, 2013; Merkoci et al., 2013; Y1lmaz, 2017) are also included in the literature. Uzunkol and Kizilelma (2016) determined the drought trends and drought conditions of Ceyhan Basin with SPI and Aridity Index (AI). As a result of their study, Elbistan to the north of the basin and Kozan and Ceyhan to the south were determined as semiarid and open to desertification areas. Çelik (2019) determined seasonal SPI drought analysis using data from 15 meteorology stations located in the Mediterranean Coast. As a result, it showed that the tendency of drought increased significantly in the Mediterranean coasts, especially in the spring 
season. In Özfidaner et al. (2018), according to the Current Drought Index (CDI) method, they obtained the index values expressing drought severity in 3,6,9, and 12 months using the monthly total flow data of the stations numbered 1801 and 1818 on the Seyhan Basin. As stated by these indexes, drought values gained importance after 2000 in 3 and 6 month periods.

According to the ÇSB (2013) report, when the meteorological data between 1950 and 2010 were examined, a statistically significant warming trend has been generally observed in the Mediterranean Region of Turkey. As very few of them are to be statistically significant, cool trends have been identified in the Black Sea region, the central and western regions of Turkey.

In this study, it is aimed to make a comprehensive drought analysis using hydrometeorological indicators, that is, monthly total precipitation, monthly average temperature, and PET values in Turkey's Eastern Mediterranean, Seyhan, Ceyhan, and Asi River Basins. The study area is located in the Mediterranean Basin of Southern Turkey having fertile land and high tourism potential. It is also considered as one of the most sensitive regions against climate change and drought. The studies highlighted above showed that both meteorological and hydrometeorological stations in the basins recorded the drought in the past, and with the help of the parametric drought indexes, the drought severity, occurrence area, and duration can be calculated. However, the future drought forecast only consists of recent interpretations. Drought analysis was performed in 35 meteorological stations in total, 8 in the Eastern Mediterranean Basin, 11 in the Seyhan Basin, 10 in the Ceyhan Basin, and 6 meteorological stations in the Asi Basin. RDI is a method used especially in arid and semi-arid areas. As Turkey is located in semiarid regions in the climate classification (Sırdaş and Şen, 2003), RDI (Tsakiris and Vangelis, 2005), one of the meteorological drought indexes, was utilized to analyze drought in the study area. The drought index values were calculated over 3-, 6-, 9-, and 12month series of overlapping RDI. Today, the mapping of the drought to see visual spatial spreading has become common. Therefore, areal mapping of the index values obtained during the observation series was carried out by using the Inverse Distance Weighted Interpolation (IDWI) Method with the help of ArcGis10.1 package program.

\section{MATERIALS AND METHODS}

\section{Materials}

In this work, the study area was identified as Eastern Mediterranean Basin, Seyhan Basin, Ceyhan Basin, and Asi Basin containing the most fertile land and four of Turkey's 25 river basins. The total size of the study area is approximately $73587 \mathrm{~km}^{2} ; 8$ meteorology observation stations in the Eastern Mediterranean Basin, 11 in the Seyhan Basin, 10 in the Ceyhan Basin, and 6 in the Asi Basin were included in the study. The monthly total precipitation and PET values measured during the observation period of these observation stations were used in the analysis. Since Mut station has 1966-1986 and 1994-2014 measurement data, it was included in the study in two series. The position of the study area in Turkey and distribution of meteorological observation stations in the basin was depicted in Figure 1. The altitude, latitude, longitude, and observation years of the stations are given in Table 1. 

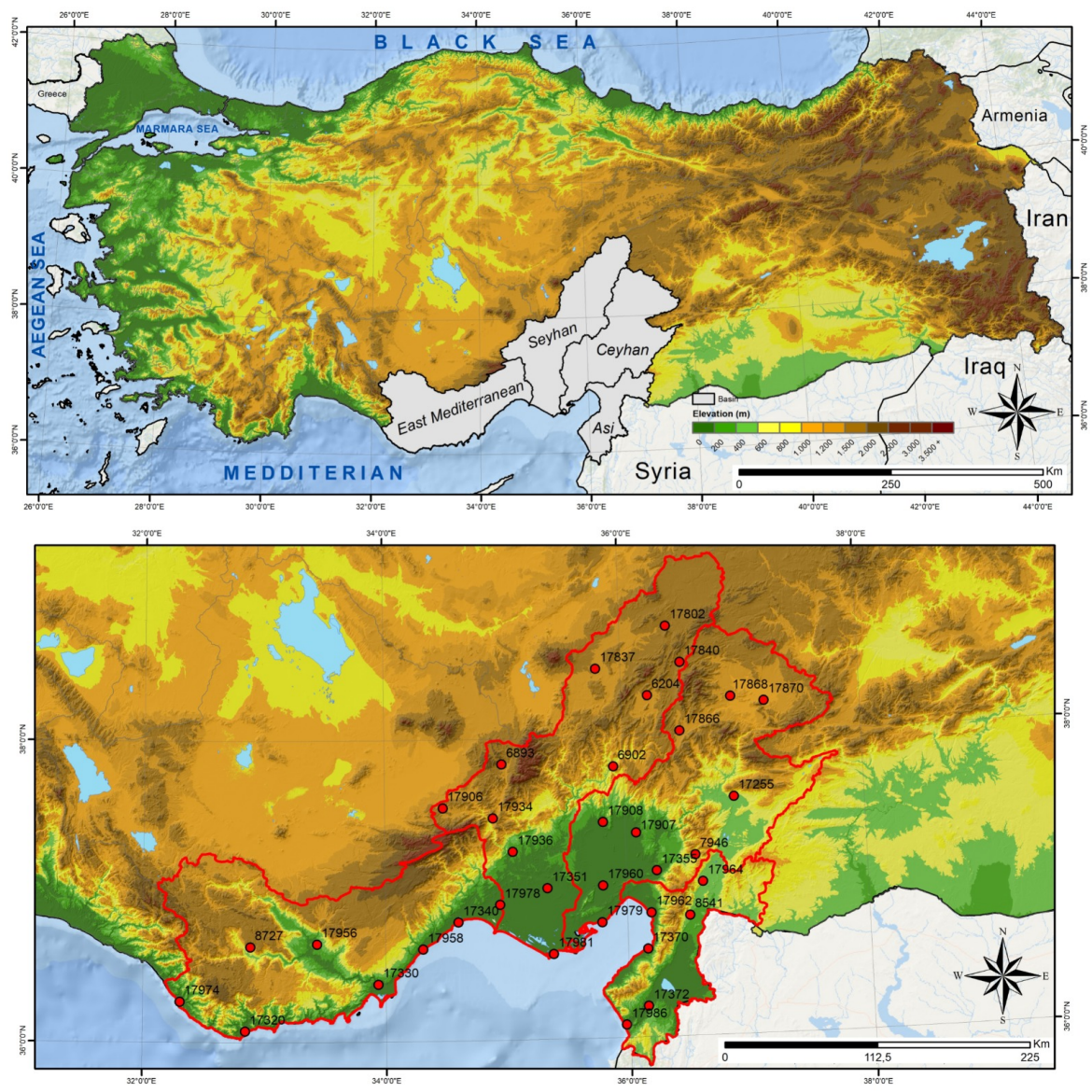

Figure 1. Location of the study area in Turkey and range of the meteorological stations.

Table 1. Information about meteorological observation stations.

\begin{tabular}{|c|c|c|c|c|c|}
\hline \multicolumn{7}{|c|}{ EASTERN MEDITERRENEAN BASIN } \\
\hline Station No & Name & Elevation (m) & X (Latitude) N & Y (Longitude) E & Observation Period \\
\hline 8727 & ERMENEK & 1280 & 36.6333 & 32.8833 & $1976-2003$ \\
\hline 17320 & ANAMUR & 2 & 36.0742 & 32.8407 & $1961-2014$ \\
\hline 17330 & SILİFKE & 10 & 36.3824 & 33.9373 & $1961-2014$ \\
\hline 17340 & MERSiN & 7 & 36.7879 & 34.6026 & $1961-2014$ \\
\hline 17956 & MUT & 340 & 36.6514 & 33.4339 & $1966-1986 / 1994-2014$ \\
\hline 17958 & ERDEMLİ & 7 & 36.6119 & 34.3085 & $1964-2014$ \\
\hline 17974 & GAZİASA & 21 & 36.2715 & 32.3045 & $1970-2014$ \\
\hline 17978 & TARSUS & 12 & 36.9 & 34.9667 & $1989-1997$ \\
\hline
\end{tabular}


128 Drought assessment using the reconnaissance drought index (RDI): A case study of Eastern Mediterranean, Seyhan, Ceyhan, and Asi basins of Turkey

\begin{tabular}{|c|c|c|c|c|c|}
\hline \multicolumn{6}{|c|}{ SEYHAN BASIN } \\
\hline Station No & Name & Elevation (m) & $\mathbf{X}$ (Latitude) $\mathbf{N}$ & Y (Longitude) E & Observation Period \\
\hline 6204 & TUFANBEYLİ & 1400 & 38.2649 & 36.2207 & $1987-2012$ \\
\hline 6893 & ÇAMARDI & 1500 & 37.8317 & 34.9842 & 1971-1994 \\
\hline 6902 & FEKE & 620 & 37.8 & 35.9167 & 1971-1994 \\
\hline 17351 & ADANA & 23 & 37.0041 & 35.3443 & $1961-2014$ \\
\hline 17802 & PINARBAŞI & 1542 & 38.7224 & 36.3924 & $1964-2010$ \\
\hline 17837 & TOMARZA & 1402 & 38.4522 & 35.7912 & $1966-2010$ \\
\hline 17840 & SARIZ & 1599 & 38.4781 & 36.5035 & 1969-2011 \\
\hline 17906 & ULUKIŞLA & 1453 & 37.548 & 34.4867 & $1963-2011$ \\
\hline 17934 & POZANTI & 1080 & 37.4758 & 34.9022 & 1964-1993 \\
\hline 17936 & KARAİSALI & 240 & 37.2505 & 35.0628 & $1965-2011$ \\
\hline 17981 & KARATAŞ & 22 & 36.5667 & 35.3833 & $1964-2011$ \\
\hline \multicolumn{6}{|c|}{ CEYHAN BASIN } \\
\hline Station No & Name & Elevation (m) & X (Latitude) $\mathbf{N}$ & Y (Longitude) E & Observation Period \\
\hline 7946 & BAHÇE & 665 & 37.2021 & 36.5863 & 1999-2012 \\
\hline 17255 & K.MARAŞ & 572 & 37.576 & 36.915 & 1963-2014 \\
\hline 17355 & OSMANIYYE & 94 & 37.1021 & 36.2539 & $1987-2014$ \\
\hline 17866 & GÖKSUN & 1344 & 38.024 & 36.4823 & $1964-2011$ \\
\hline 17868 & AFŞİN & 1230 & 38.2405 & 36.919 & $1971-2010$ \\
\hline 17870 & ELBİSTAN & 1137 & 38.2038 & 37.1982 & 1964-2011 \\
\hline 17907 & KADİRLİ & 86 & 37.3575 & 36.0907 & 1999-2012 \\
\hline 17908 & KOZAN & 112 & 37.4337 & 35.8188 & 1964-2011 \\
\hline 17960 & CEYHAN & 48 & 37.0132 & 35.8055 & $1965-2011$ \\
\hline 17979 & YUMURTALIK & 34 & 36.7687 & 35.7903 & $1965-2011$ \\
\hline \multicolumn{6}{|c|}{ ASI BASIN } \\
\hline Station No & Name & Elevation (m) & X (Latitude) $\mathbf{N}$ & Y (Longitude) E & Observation Period \\
\hline 8541 & HASSA & 460 & 36.8 & 36.5167 & $1978-2003$ \\
\hline 17370 & İSKENDERUN & 4 & 36.5888 & 36.155 & 1964-2014 \\
\hline 17372 & ANTAKYA & 104 & 36.2048 & 36.151 & $1961-2014$ \\
\hline 17962 & DÖRTYOL & 29 & 36.8244 & 36.198 & 1961-2011 \\
\hline 17964 & İSLAHİYE & 518 & 37.0209 & 36.6319 & $1975-2010$ \\
\hline 17986 & SAMANDAĞ & 4 & 36.0814 & 35.949 & $1965-2011$ \\
\hline
\end{tabular}




\section{Method}

\section{Reconnaissance Drought Index (RDI)}

The Reconnaissance Drought Index was first proposed by (Tsakiris and Vangelis, 2005) for monitoring agricultural and meteorological drought. It only needs cumulative Precipitation (P) and PET data. While calculating the drought index, four different methods are recommended to examine evapotranspiration. These are Hargreaves, Thornthwaite, Blaney-Criddle, and Penman-Monteith methods, respectively.

The Reconnaissance Drought Index is expressed as $\left(\alpha_{\mathrm{k}}^{\mathrm{i}}\right)$ ve $\mathrm{RDI}_{\mathrm{st}}$ (Standardized RDI). In order to calculate the Reconnaissance Drought Index, it is first necessary to calculate the Reconnaissance Drought Index initial value $\left(\alpha_{\mathrm{k}}^{\mathrm{i}}\right)$. $P$ and PET respectively showed i. year, $\mathrm{j}$ month $(\mathrm{j}=1$ October, $\mathrm{j}=12$ September) of the precipitation and potential evapotranspiration, $\mathrm{N}$ as the number of hydrological years, $\mathrm{k}$ as 1 to 12 months; thus, it can be calculated as in $\alpha_{\mathrm{k}}^{\mathrm{i}}$ Eq.1.

$\alpha_{k}^{i}=\frac{\sum_{j=1}^{k} P_{i j}}{\sum_{j=1}^{k} P^{k} T_{i j}} \quad i=1 \ldots . . . N, j=1 \ldots \ldots k$

$\alpha_{\mathrm{k}}^{\mathrm{i}}$ values match both lognormal and gamma distribution at various locations and at various time intervals (Tsakiris and Vangelis, 2005).

The Anderson-Darling (Anderson and Darling, 1952) test was used to determine whether the $\alpha_{\mathrm{k}}^{\mathrm{i}}$ (RDI initial value) values of the stations used in the study were normal or not. As a result, it was determined that some periods of some stations show normal distribution, while others do not. Since the normal distribution does not fit all of the stations used in the study, Gamma Distribution was used in this study as suggested by Tsakiris and Vangelis (2005). Thom (1958a) stated that gamma distribution function fits best with the precipitation series.

When Gamma distribution function is used, $\mathrm{RDI}_{\text {st }}$ can be obtained by calculating the probability density function of the Gamma distribution. The gamma distribution probability density function $\mathrm{g}(\mathrm{x})$ is found as follows (Eq. 2). Here, $\alpha$ shape parameter, $\beta$ scale parameter and $\mathrm{x}$ are the cumulative precipitation amount. $\alpha$ and $\beta$ are estimated for each station and each time interval (Vangelis et al., 2013).

$g(x)=\frac{1}{\beta^{\alpha} \Gamma(\alpha)} x^{\alpha-1} e^{\frac{-x}{\beta}} \quad x, \alpha, \beta>0$

$\Gamma(\alpha)$ is gamma function.

$\Gamma(\alpha)=\int_{0}^{\infty} y^{a-1} e^{-y} d y$

While calculating the Reconnaissance Drought Index, the gamma density function is adapted to the frequency distribution, which is the cumulative precipitation values of $3,6,9$, and 12 months.

The estimation of $\alpha$ and $\beta$ can be done as follows in Eq. (4), (5), and (6) (Thom, 1966b):

$\widehat{\alpha}=\frac{1}{4 \mathrm{~A}}\left(1+\sqrt{1+\frac{4 \mathrm{~A}}{3}}\right)$

$\widehat{\beta}=\frac{\bar{x}}{\widehat{\alpha}}$ 
$\mathrm{A}=\ln (\overline{\mathrm{x}})-\frac{\sum \ln (\mathrm{x})}{\mathrm{N}}$

The result parameters are then used to find the cumulative probability of $\alpha_{\mathrm{k}}$ for the hydrological year desired to be calculated in the study area. The composite cumulative probability function can be used when the gamma function $\mathrm{x}=0$ (i.e., cumulative precipitation values for the selected period are $0 \mathrm{~mm}$ ). In this case $\mathrm{RDI}_{\text {st }}$ can be found with the help of the cumulative probability function in Eq. 7 (Vangelis et al., 2013).

$H(x)=q+(1-q) G(x)$

$\mathrm{q}$ is the probability of precipitation being zero, $\mathrm{G}(\mathrm{x})$, the adjoint probability of the gamma distribution, and $\mathrm{m}$ is the number of zeros in the $\alpha_{\mathrm{k}}$ time series. It is calculated as in Eq. 8. Cumulative probability H (x) replaces $\mathrm{G}(\mathrm{x})$ (Vangelis et al 2013).

$\mathrm{q}=\frac{\mathrm{m}}{\mathrm{n}}$

Positive $\mathrm{RDI}_{\mathrm{st}}$ values show wetlands according to normal conditions of the study area, and negative $\mathrm{RDI}_{\mathrm{st}} \mathrm{values}$ indicate dry periods. The severity of drought increases when $\mathrm{RDI}_{\mathrm{st}}$ values drop. Drought severity can be categorized as no drought (ND), mild drought (MD), moderate drought (MOD), severe drought (SD) and extreme drought (ED). $\mathrm{RDI}_{\text {st }}$ values are respectively ND (>0), MD (0 to -1$)$, MOD (-1 to -1.5$)$, SD (-1.5 to -2$)$ and ED (less than -2 ) (Tsakiris and Vangelis, 2005; Vangelis et al., 2013).

Since the hydrological year starts in October, it is calculated for the 3-month $\mathrm{RDI}_{\text {st }}$ (October-December), 6month RDI st $_{\text {(October-March), 9-month RDI }}$ (October-June), 12-month RDI st $_{\text {(October-September). This ensures }}$ that $\mathrm{RDI}_{\mathrm{st}}$ has a different structure than other drought indexes. $\mathrm{RDI}_{\mathrm{st}}$ is calculated for reference periods. It is not calculated as fixed time floating indexes (Topçu, 2018).

In this study, Thornthwaite potential evapotranspiration method was used in the Reconnaissance Drought Index calculation. Thornthwaite method was proposed by (Thornthwaite, 1948) and widely used. It assumes that the evapotranspiration temperature does not occur at $0{ }^{\circ} \mathrm{C}$ or below. This method estimates potential evapotranspiration as in Eq. 9.

$\operatorname{PET}=16 \cdot\left(\frac{\mathrm{N}}{12}\right) \cdot\left(\frac{\mathrm{m}}{30}\right) \cdot\left(10 \cdot \frac{\mathrm{T}_{\text {mean }}}{\mathrm{I}}\right)^{\mathrm{a}}$

$\mathrm{T}_{\text {mean }}$ monthly average temperature $\left({ }^{0} \mathrm{C}\right)$, $\mathrm{N}$ monthly average daylight hour (hour / day), m number of days in each month, coefficient a can be calculated with the help of Eq. 10 (Yoo and Boyd, 1994).

$a=6.75 \times 10^{-7} \times I^{3}-7.71 \times 10^{-5} \times I^{2}+1.79 \times 10^{-2} \times I+0.49$

Finally, I heat index is the sum of 12 months values. It is found as in Eq. 11.

$\mathrm{I}=\sum_{\mathrm{i}=1}^{12}\left(\frac{\mathrm{T}_{\mathrm{imean}}}{5}\right)^{1.514}$

$\mathrm{N}$ values were determined by using the latitudes of the meteorological stations used in the study. With the Thornthwaite method, after finding PET (potential evapotranspiration), RDI is calculated as described using the precipitation data. Index values for 3, 6, 9 and 12 month cumulative periods starting from October are calculated. 


\section{Mapping of Drought}

In this study, drought mapping is carried out using annual $\mathrm{RDI}_{\mathrm{st}}$ values of stations with common observation years to monitor visual spatial spread of drought. As a method, the most commonly used IDWI Method is used in mapping. This method accepts the assumption that the points that are clearly close together are more similar to those of distant ones. In this method, the parameter of a point without measurement is estimated by using the points around that place that are measured. It also assumes that the local effect of each measured point decreases with distance and produces a superficial interpolation based on the weighted average of the points. It is used to represent geographic, hydrological, and meteorological phenomena.

The $p$ parameter is important for the IDWI calculator. $p$ is the base that determines the assigned weight of each of the observations. It is generally considered to be $p=2$ (default value). When $p=1$, it smooths the interpolated surface. When $p=2$, it increases the effect from known points. The number of points near the point also affects the accuracy of the result.

The IDWI calculator can found as in $\mathrm{Z}_{\mathrm{p}}$ Eq.12.

$\mathrm{Z}_{\mathrm{p}}=\frac{\sum_{\mathrm{i}=1}^{\mathrm{n}} \frac{\mathrm{z}_{\mathrm{i}}}{\mathrm{d}_{\mathrm{i}}^{\mathrm{p}}}}{\sum_{\mathrm{i}=1}^{\mathrm{n}} \frac{1}{\mathrm{~d}_{\mathrm{i}}^{\mathrm{p}}}}$

Here $d_{i}^{p}$, the distance between the observation point $Z_{i}\left(R D I\right.$ value at point $i$ ) and the prediction point $Z_{p}$ (estimated RDI value at point $\mathrm{p}$ ) indicated the total number of points $\mathrm{n}$. In this study, drought mapping was created with the help of ArcGis 10.1 package program (ESRI 2012). While mapping, the observation times of the Ermenek, Tarsus, Çamard1, Feke, Pozantı, and Hassa stations were excluded from the study since 1999-2010, which is the common observation period of the other stations, was excluded.

\section{RESULTS AND DISCUSSION}

\section{PET Results of the Eastern Mediterranean, Seyhan, Ceyhan, and Asi Basins}

Since there are similar PET changes in other basins, it is preferred to show only the PET changes of Seyhan Basin. The reason why Seyhan Basin is preferred is that it has the highest number of meteorological stations. PET changes of Seyhan Basin can be seen in Figure 2. The PET values of almost all stations increased over time. This may be due to an increase in temperature, not an increase in precipitation. Because the record-breaking temperatures seen in recent years, especially in the summer have increased evaporation and sweating. PET values increased more

frequently especially after 1990s. According to the study conducted by (Türkeş et al., 2000), global warming caused by greenhouse gas became more evident especially after 1980s and reached its highest values in 1990s. 1998 was the hottest year since 1860, according to globally calculated average annual surface temperatures. In 1998, the average annual temperature of the Earth close to the surface was calculated to be $0.57^{\circ} \mathrm{C}$ warmer than normal (WMOB, 1999). When Figure 2 is analyzed, the PET values in stations with measurements in 2008 and 2010 exceeded $1000 \mathrm{~mm} /$ year. Based on these studies, the increase observed in PET values is thought to be caused by global warming. 

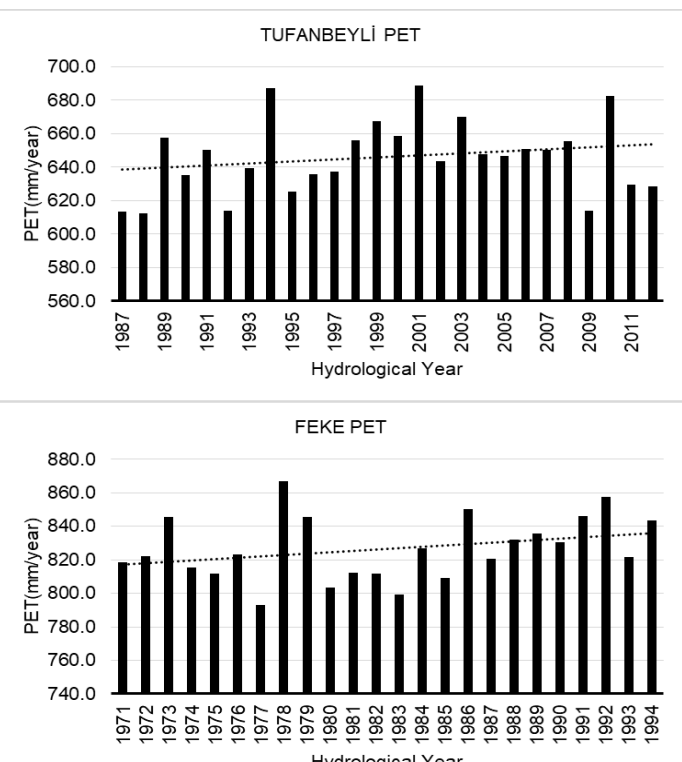

Hydrological Year
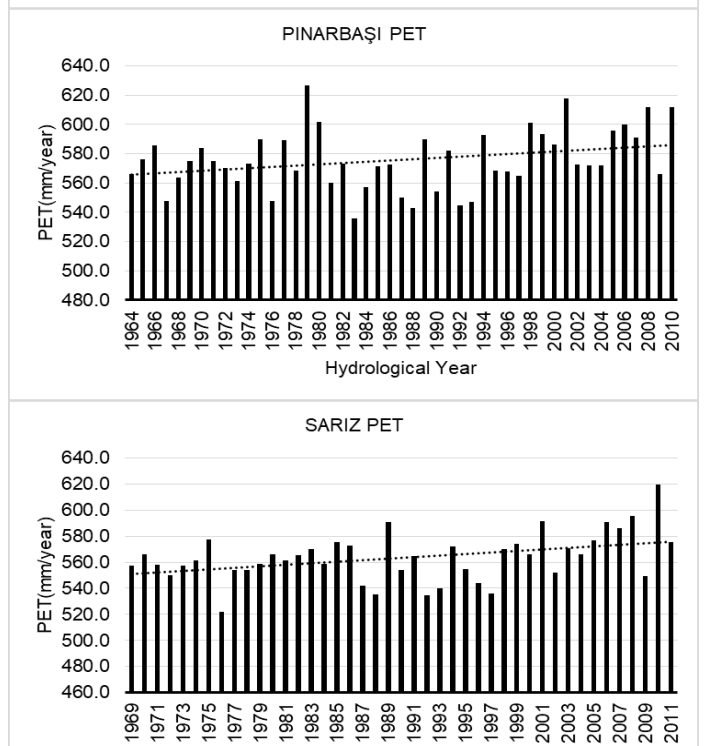

Hydrological Year

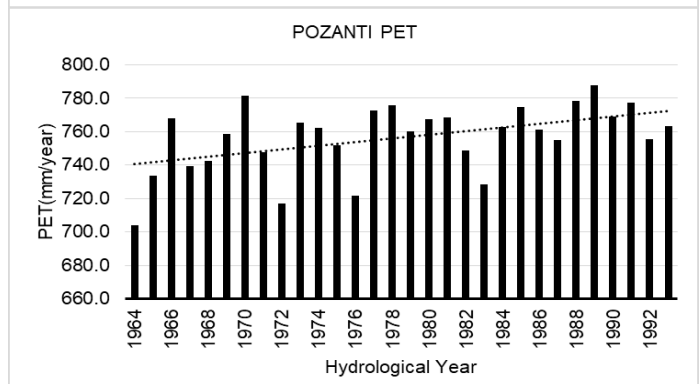

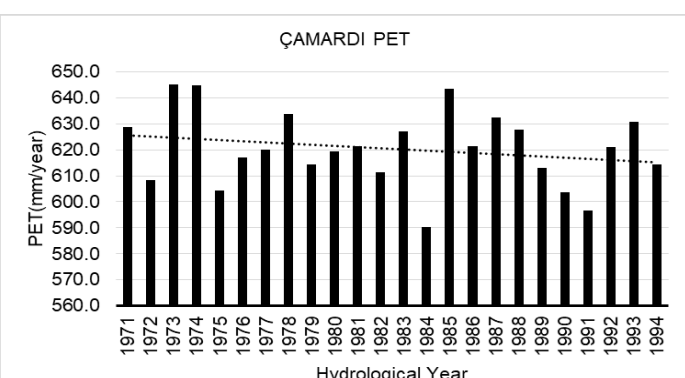

Hydrological Year
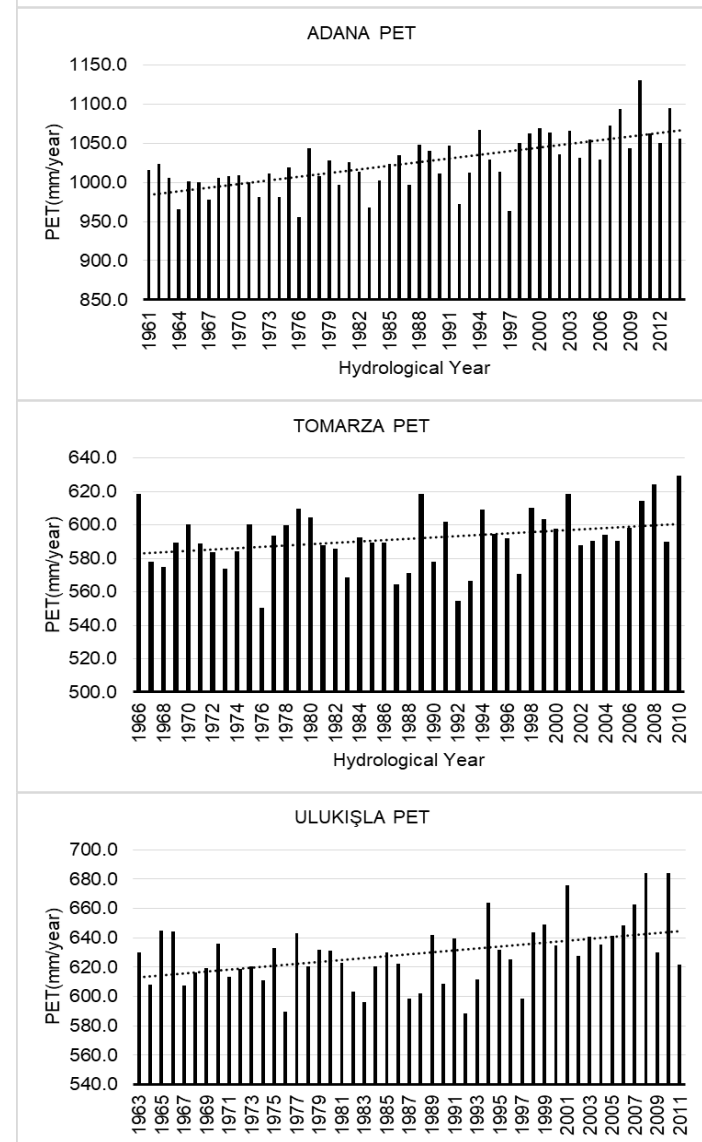

Hydrological Year

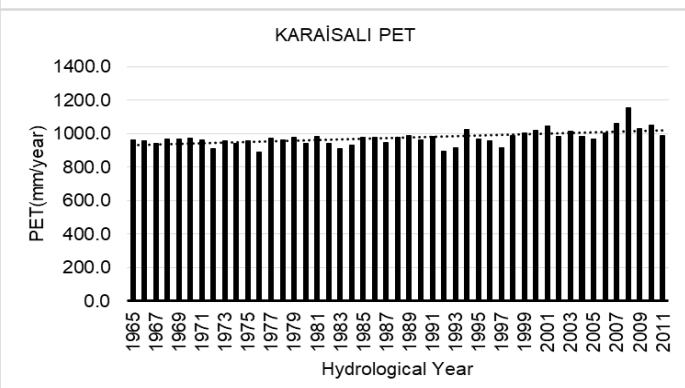

Figure 2. Annual PET variations of Seyhan Basin stations. 


\section{RDI Results of the Eastern Mediterranean, Seyhan, Ceyhan, and Asi Basins}
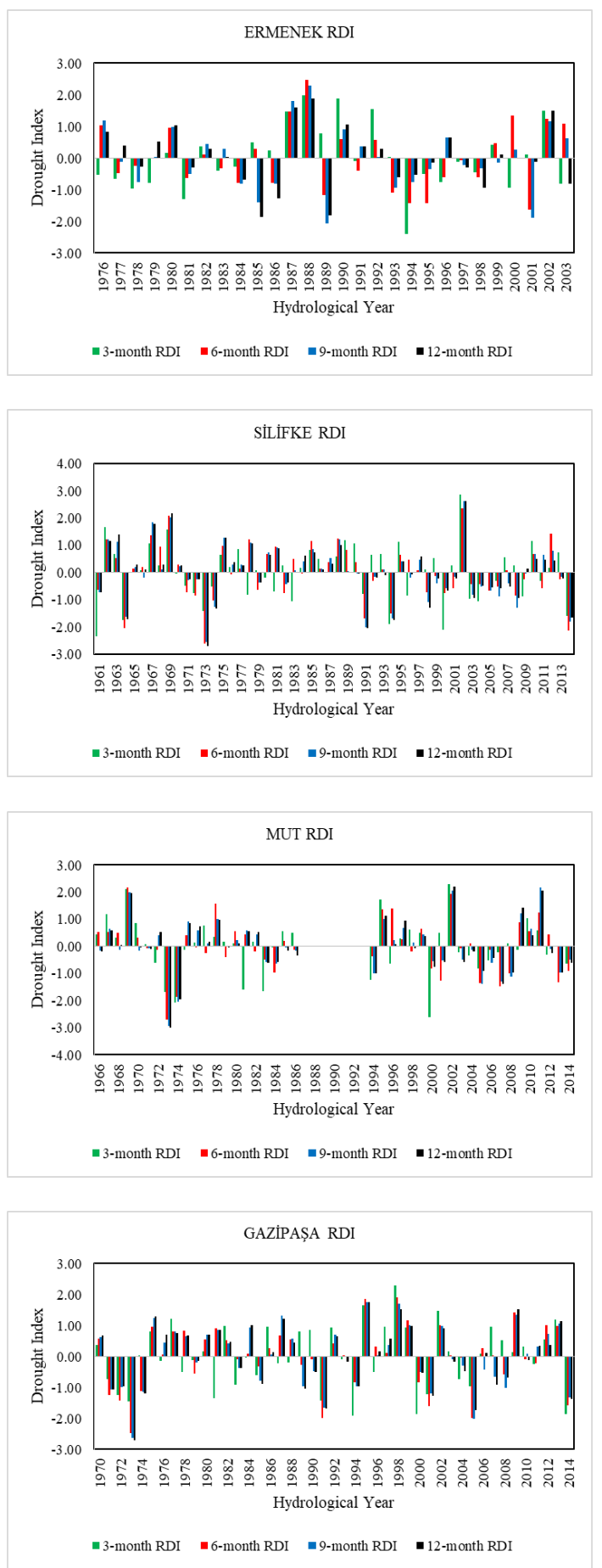
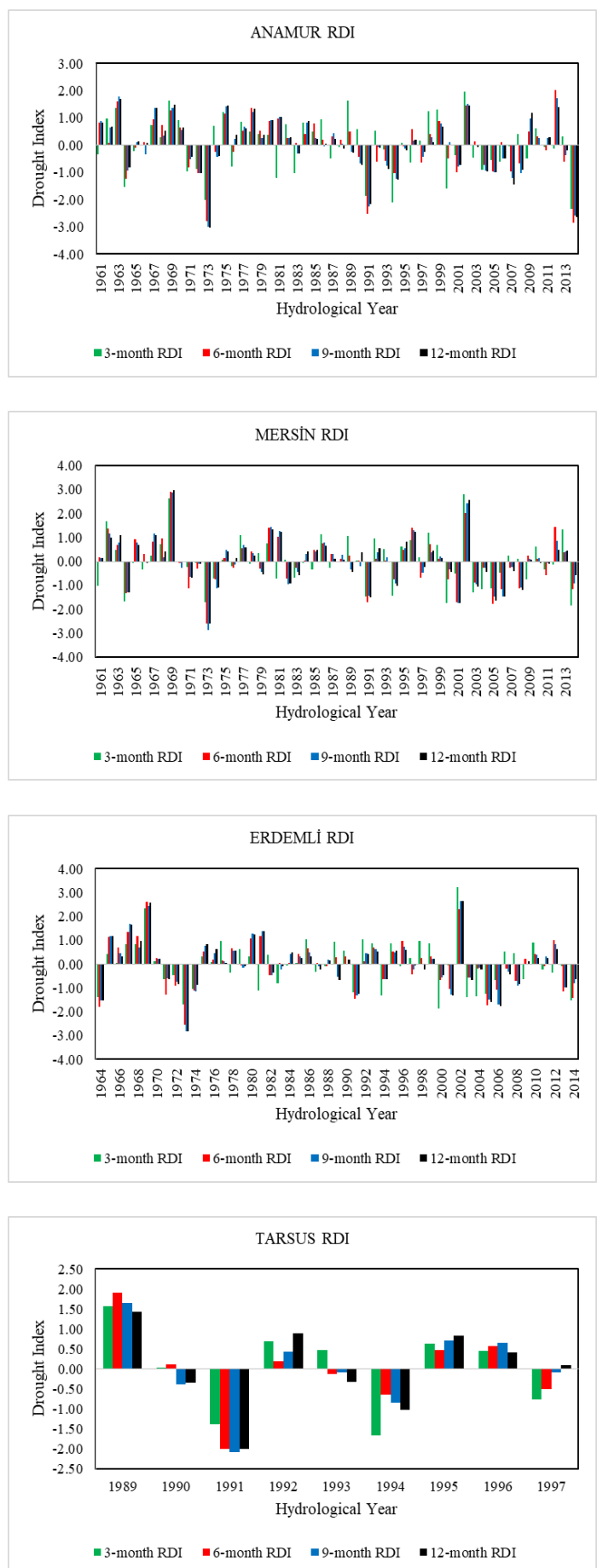

Figure 3. Annual RDI values of Eastern Mediterranean Basin stations. 

basins of Turkey

While 3- and 6-Month RDI values analyze seasonal drought, 9- and 12-Month RDI values determine medium term and all hydrological year drought. In the graphs depicted in Figure 3, annual RDI values change in the 3-, 6-, 9, and 12-Month periods of the Eastern Mediterranean Basin stations. As a result of the analysis, how many years the drought lasted can be traced. According to Figure 3, the drought lasted 5 years between 1971-1975 and 6 years between 2003-2008 in the basin. In 1973, there was a severe drought throughout the basin. In 1964, severe drought level was reached at Mersin, Erdemli, Silifke, and Anamur stations. It indicated that there was a severe drought in the stations that measured in 1991, 1994, 2001, and 2014. The year 2002 was wetland across the basin.
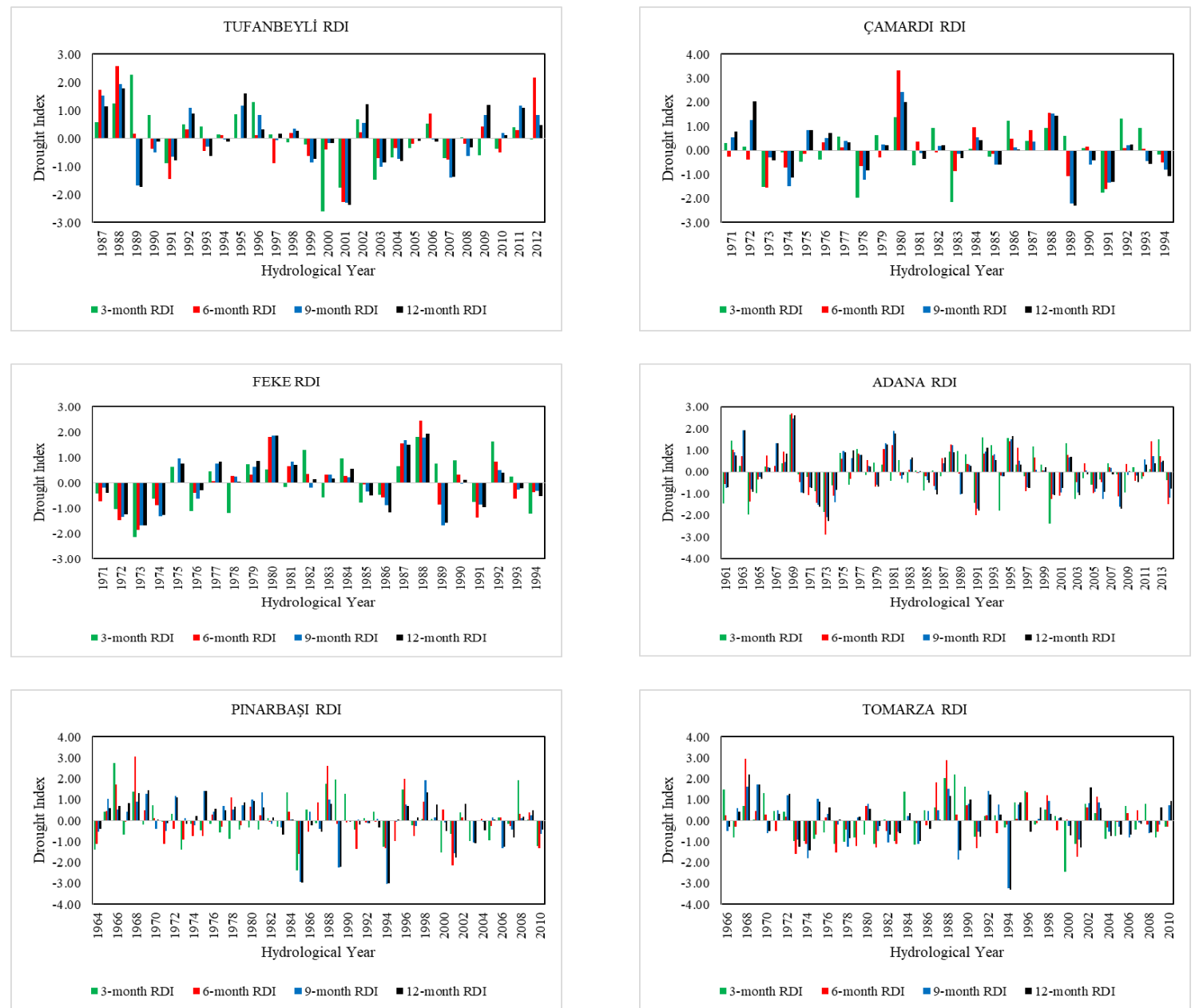

Figure 4. Annual RDI values of some Seyhan Basin stations.

Figure 4 depicted the changes in annual RDI values of Seyhan Basin stations. In general, 9-Month and 12-Month RDI values gave consistent results. According to Figure 4, moderate drought was experienced in Pınarbaşı station, which was measured in 1964. Drought was observed in the basin between 1970-1975. Traces of the drought of 1973, which took its place in history, were observed throughout the basin. The year 1973 was determined as extremely arid especially in Adana, Feke, Ulukışla, Pozantı, Karaisalı, and Karataş stations. The highest drought severity across the basin was detected at Tomarza station in 1994. In 2000, severe drought throughout the basin continued as an extreme drought in 2001, and in 2002, there was a clearly observed marshiness in almost all stations. From 2003 to 2009, moderate drought and even severe drought were observed in Tufanbeyli, Adana, Pınarbaşı, Tomarza, Karaisalı, and 
Karataş stations. The extremely drought years across the basin were identified as 1973, 1991, 1994, 2001, and 2014. Moderate drought was detected at the stations in the basin between 2003-2008. The annual RDI charts of the Ceyhan Basin are not given due to the similar results with other basins. Drought is observed in the Ceyhan basin between 1970-1975. In 1973, it was determined that there was extreme drought at Kahramanmaras, Afşin, Kozan, Ceyhan, and Yumurtalık stations. It is noteworthy that in 1989, there were extreme drought in Osmaniye, Elbistan and Ceyhan stations, severe drought in Göksun and Yumurtalik stations, medium drought in Kahramanmaraş and Afşin stations and mild drought in Kozan station. Although their severity was different between 1999 and 2001, almost all stations across the basin experienced drought. In particular, the drought in 2001 was detected as moderate drought or over from the graphs. In 2014, measured K.Maraş and Osmaniye stations experienced extreme drought. Especially in Afşin, Kozan, Elbistan, and Göksun stations of the basin, an increase in the frequency of drought was observed after 1997.
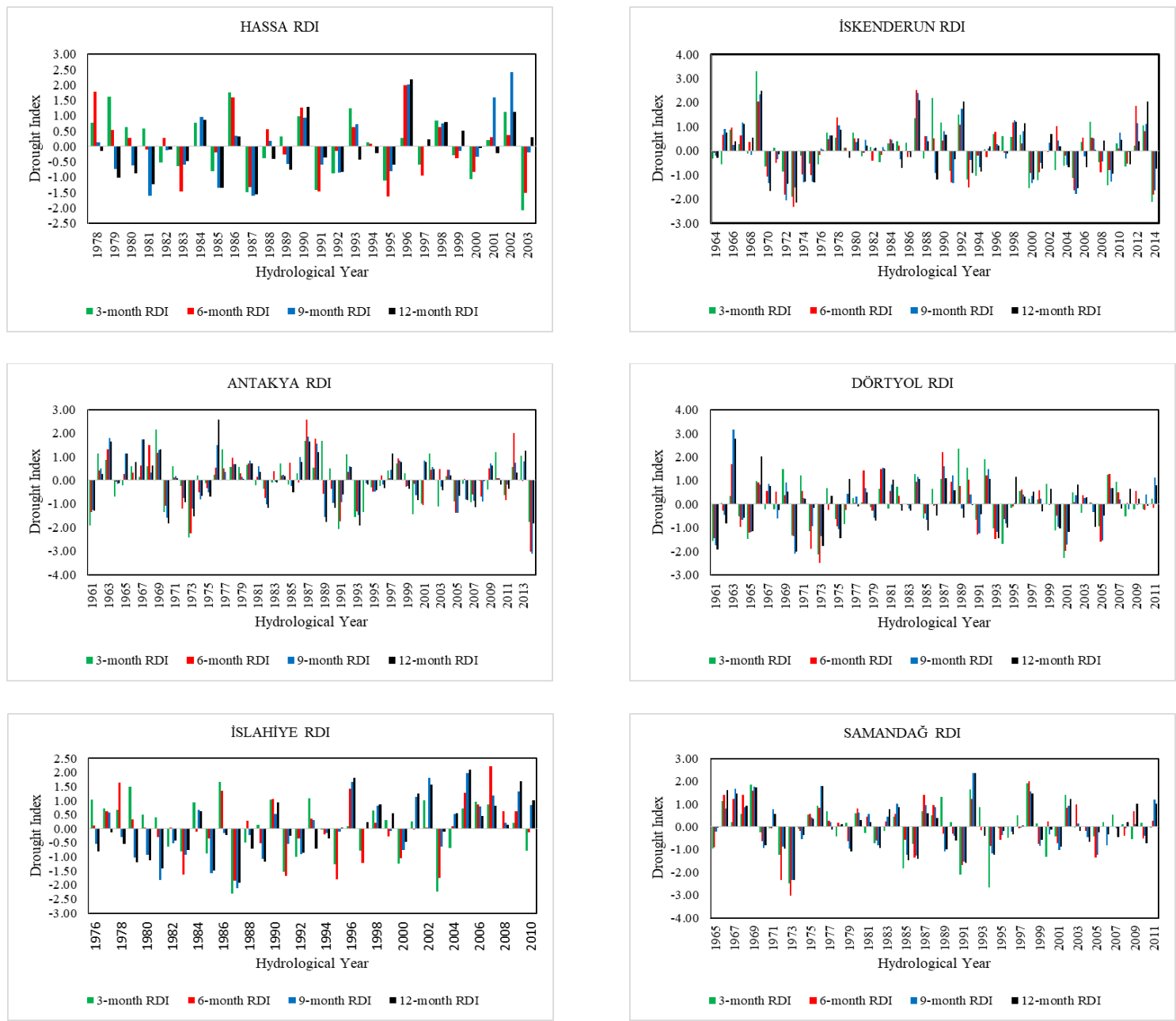

Figure 5. Annual RDI values of Asi Basin stations.

Figure 5 depicted the annual changes in the Asi basin stations 3-, 6-, 9-, and 12-Month RDI values. The basin experienced the longest drought at İskenderun station between 1970 and 1976. Drought was observed in all stations with measurements in 1970, 1972 and 1973. As in other basins, it was determined that the Asi basin experienced extreme drought in 1973. When the Asi basin is examined, it has been observed that Hassa and İslahiye stations, 
which have higher elevations, experienced severe and extreme drought in 1987, respectively. For Iskenderun, Antakya, Dörtyol and Samandağ stations, which have lower elevations, excessive watery were passed. Moderate drought severity was observed in 1991 and 2000 throughout the basin. 2005 has been a severe arid season for Antakya, Dörtyol, and İskenderun stations. For example, in Iskenderun and Antakya stations, which were measured until 2014, there was a severe watery in 2013, while extreme drought in 2014. Similarly, it manifests itself in Hassa and İslahiye stations as severe watery in 2002 and severe drought in 2003.
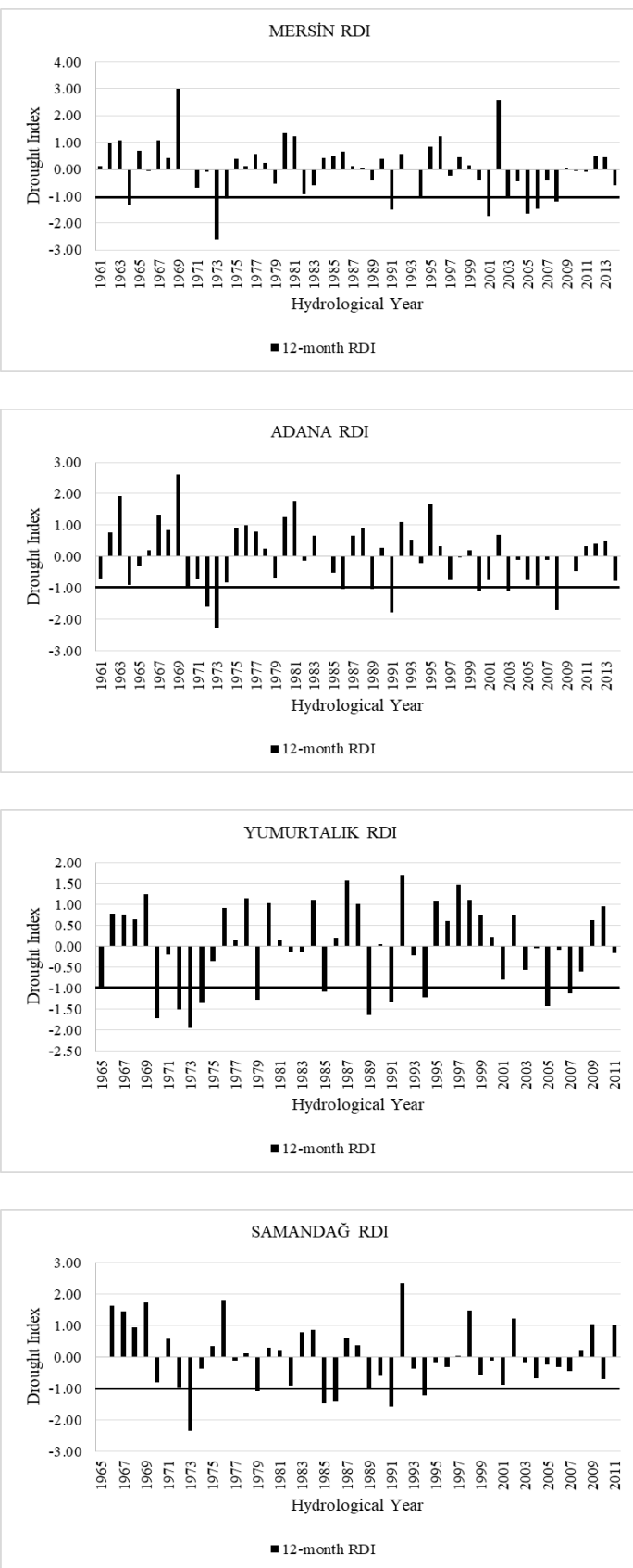
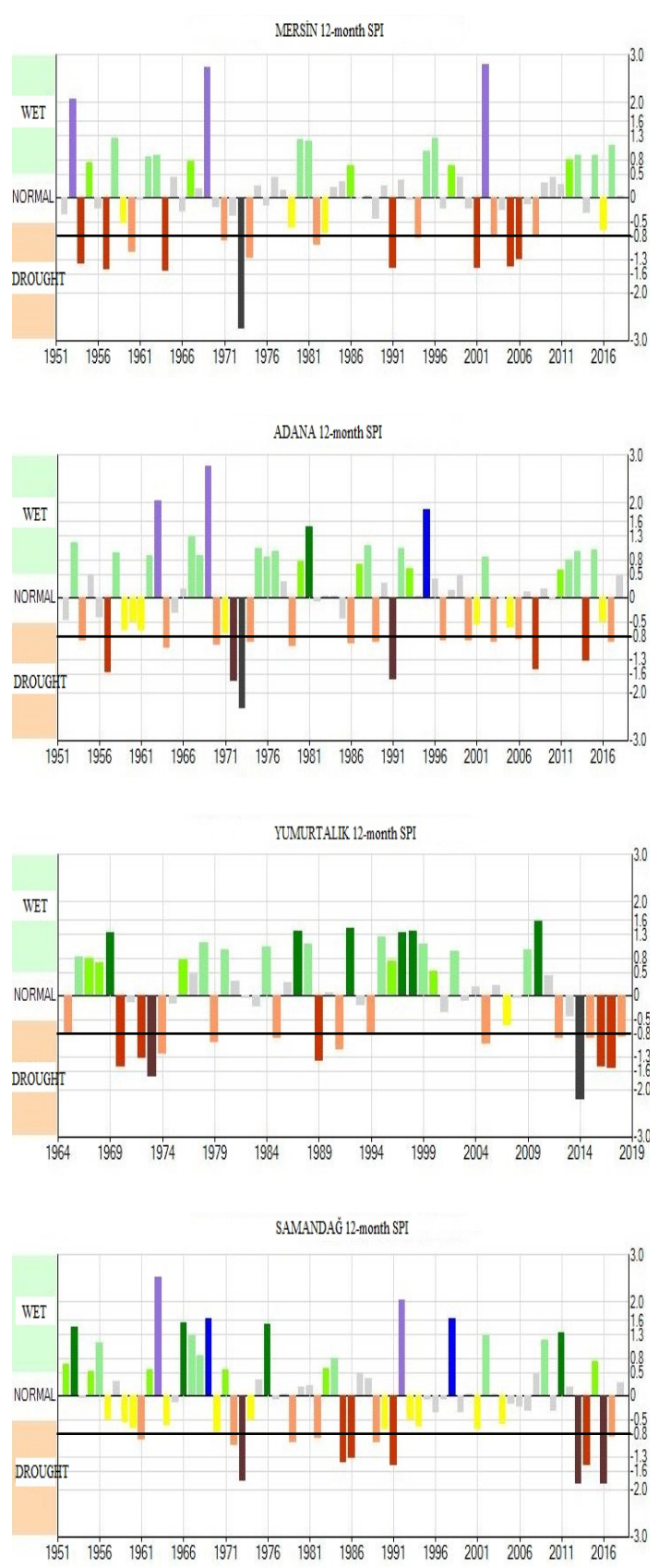

Figure 6. Comparison of annual RDI and SPI values of Mersin, Adana, Yumurtalık, and Samandağ stations. 
Figure 6 depicted the comparison of the annual RDI values of Mersin, Adana, Yumurtalık, and Samandağ stations with the drought analysis values made by the Turkish State Meteorology according to SPI method (MGM 2020a). According to the RDI results from each region, stations that show similar arid periods with other stations and have relatively longer observation values were selected and compared with the results of Turkish State Meteorology. According to these results, RDI values less than "-1" and SPI value less than "-0.8" represent moderate drought and above in drought grading (MGM 2020b). Due to this limitation, the years above the moderate drought yield similar results compared to Figure 6 when compared with those of both methods. For example, the same drought degrees were determined for Mersin station in 1964, 1973, 1974, 1982, 1991, 1994, 2001, 2003, 2005, 2006, and 2008, for Adana station 1964, 1970, 1972, 1973, 1986, 1989, 2000, 2003, 2006, and 2008 years, for the Yumurtalik station in 1965, 1970, 1972, 1973, 1974, 1979, 1985, 1989, 1991, 1994, and 2005, and for Samandağ station in 1972, 1973, $1979,1982,1985,1986,1989$, and 1991 by both methods.

Although the results are similar, some issues should be considered. SPI uses only rainfall data, RDI utilizes both rainfall and temperature data. Therefore, RDI is more forceful as two meteorological parameters are included. SPI is based on the probability of precipitation, RDI is based on both cumulative precipitation and PET, in which PET is calculated using the Thorntwaite method.

\section{Results of Drought Mapping}

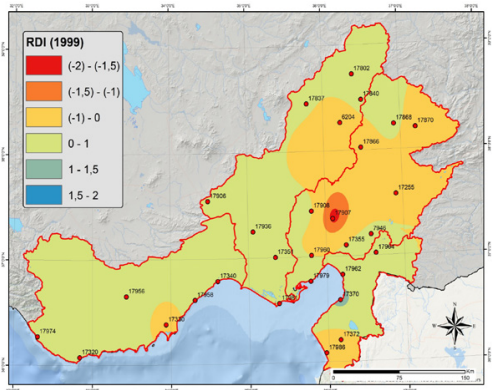

1999 RDI

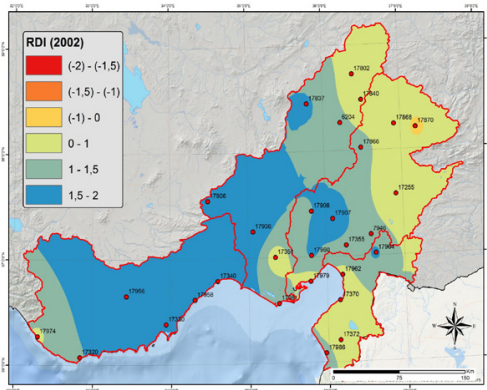

2002 RDI

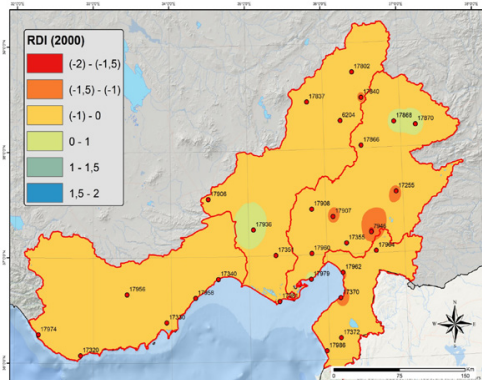

2000 RDI

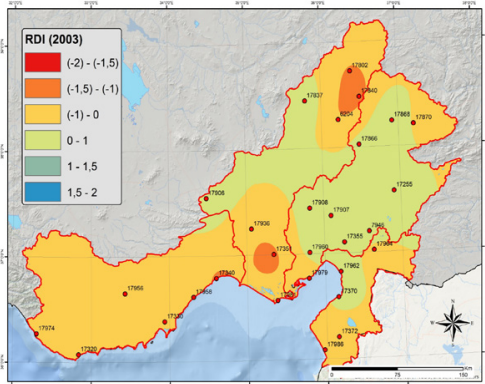

2003 RDI

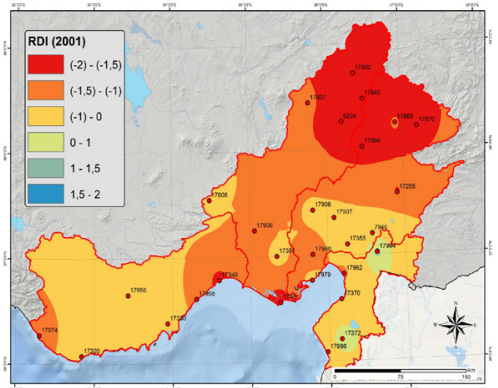

2001 RDI

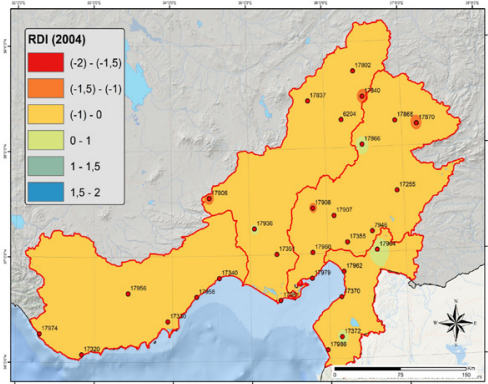

2004 RDI 


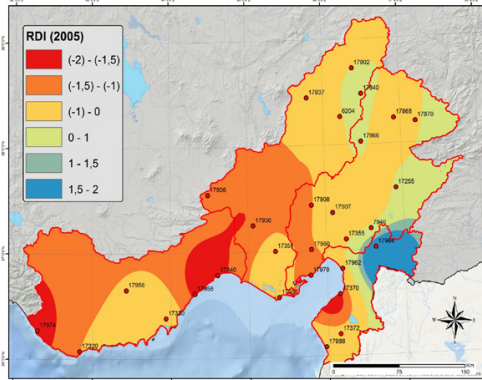

2005 RDI

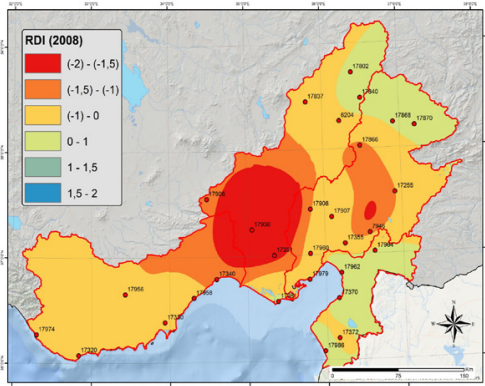

2008 RDI

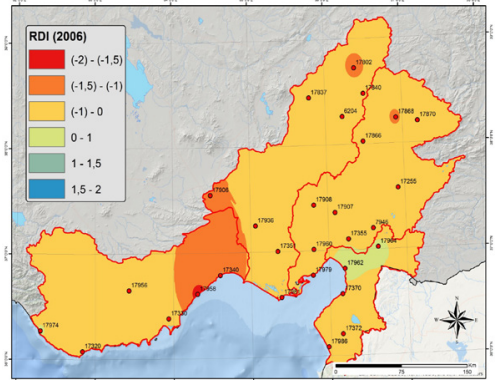

2006 RDI

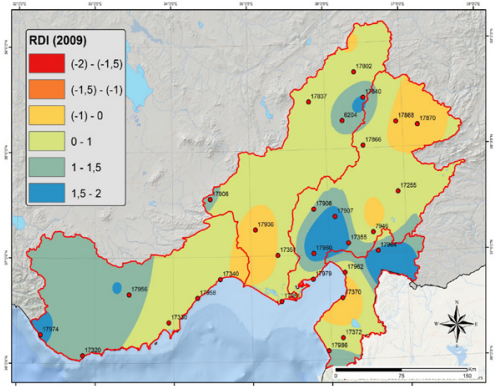

2009 RDI

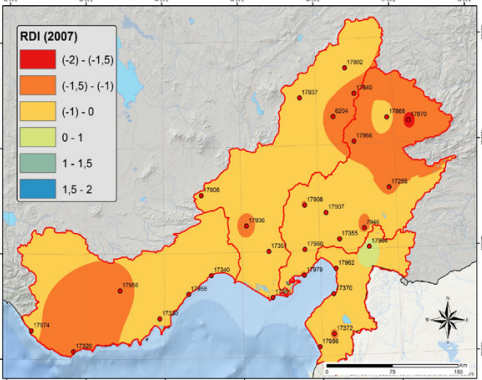

2007 RDI

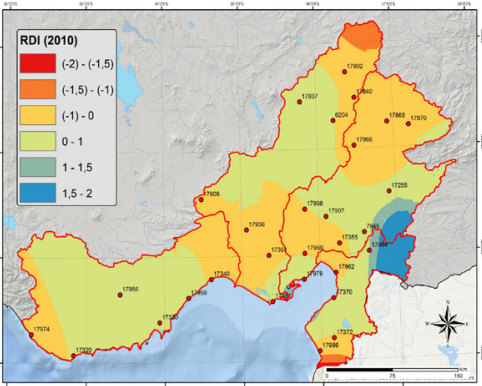

2010 RDI

Figure 7. Whole basin RDI maps between years 1999-2010.

Mapping results are shown in Figures 7. RDI results show that there was severe drought in the entire basin except for the northern end of the study area in 1973. According to the RDI, the northern part of the study area in 1985 , the central parts of the basin in 1989, the southwestern

beaches in 1991, the northernmost part in 1994, and the northeastern parts in 2001 experienced severe drought. In the mapping process, the observation times of the Ermenek, Tarsus, Çamardı, Feke, Pozantı and Hassa stations were excluded from the study since their observation period does not include the common observation period (19992010) of the other stations. RDI values of Ermenek and Hassa stations calculated according to the measurement results between 1999 and 2003 are set out in Table 2. Although these stations are not used in the mapping process, the values given in the table remain within the drought range for both stations.

Table 2. Calculated RDI values of Ermenek and Hassa stations for the period 1999-2003.

\begin{tabular}{|c|c|c|}
\hline Years & Ermenek (8727) RDI & Hassa (8541) RDI \\
\hline 1999 & 0.12 & 0.51 \\
\hline 2000 & -0.01 & -0.06 \\
\hline 2001 & -0.11 & -0.21 \\
\hline 2002 & 1.50 & 1.13 \\
\hline 2003 & -0.82 & 0.31 \\
\hline
\end{tabular}




\section{CONCLUSION}

The different methods of calculation and the different parameters used in the drought indexes create difference in terms of drought. Therefore, adhering to a single drought index can lead to a uniform interpretation of a region's drought. In this study, it is aimed to contribute to the literature by bringing a different interpretation to the region in terms of drought by using the Reconnaissance Drought Index (RDI), which has not been conducted in the region. The results that are compatible with the SPI method used by Turkish State Meteorology prove the accuracy of the this study. The drought degree of Ermenek and Hassa stations obtained as a result of mapping was found to be the same with the calculated values. This result has shown us that mapping it can provide a prediction of drought forecast for nonmeasurement points. As a result of the analysis, it was determined that there was an increase in the PET values, indicating that the drought was experienced throughout the basin, and especially the drought should be taken

seriously in all stations. The increase in PET values in all stations without exception suggests that it might be due to increasing temperatures. Therefore, the best way to avoid drought, which is not clear where or when it will occur, is to raise awareness of the public to make optimum use of watery periods and to use the available water resources in the most beneficial way.

\section{REFERENCES}

Agha, M.A.M.O. \& Şarlak N. 2017. Analysis of meteorological drought in Iraq using the reconnaissance drought index (RDI). International Journal of Advanced Research (IJAR) 5(3): 473-479.

Agnew, C.T. 1990. Spatial aspects of drought in the Sahel. Journal of Arid Environments 18: 279-293.

Agnew, C. \& Warren, A. 1996. A framework for tackling drought and land degradation, Journal of Arid Environments 33: 309-320.

American Meteorological Society (AMS) 2004. Statement on meteorological drought. Bull. Am. Meteorol. Soc $85,771-773$.

Anderson, T.W. \& Darling, D.A. 1952. Asymptotic theory of certain "goodness-of-fit" criteria based on stochastic processes. Annals of Mathematical Statistics 23: 193- 212.

Anlı, S.A. 2014. Güneydoğu Anadolu bölgesinde referans bitki su tüketiminin (ETo) zamansal değişimi ve RDI (Keşif Kuraklık İndeksi) yöntemiyle meteorolojik kuraklık analizi. Tarım Bilimleri Dergisi 20: 248-260.

Çelik, M.A. 2019. Akdeniz kıyılarında ekstrem nemli ve kurak mevsimlerin dağılımı (1967-2016), Academic Platform Journal of Engineering and Science 7-1, 56-66.

Çevre ve Şehircilik Bakanlığı (ÇŞB) 2013. Türkiye iklim değişikliği 5. bildirimi. 288s Retrieved in March, 1, 2020 from, http://www.dsi.gov.tr/docs/iklimdegisikligi/

Environmental Systems Research Institute (ESRI) 2012. ArcView GIS version 10.1. A computer software to visualize, explores, query and analyze data spatially, USA.

Hınıs, A.M. 2013. Bütünleşik kuraklık indeksi ile Aksaray'da hidrometeorolojik kuraklık analizi. Journal of the Faculty of Engineering and Architecture of Gazi University, Cilt 28, No 4, 711-721.

Malakiya, D.A. \& Suryanarayana, V.M.T. 2016. Assessment of drought using standardized precipitation index (SPI) and reconnaissance drought index (RDI): a case study of Amreli District, International Journal of Science and Research (IJSR), Volume 5 Issue 8.

Mckee, T.B., Doesken, N.J. \& Kleist, J. 1993. The Relationship of Droght Frequency and Duration to Time Scales. Reprints, 8th Conference on Applied Climatalogy, Anaheim, CA, USA, 179-184 p. 
Merkoci, L.A., Mustaqi, V., Mucaj, L. \& Dvorani, M. 2013. Arnavutluk bölgesinde kuraklık ve standart yağış indeksinin (SPI) kullanımı, Journal of the Faculty of Engineering and Architecture of Gazi University, Vol 28, No 1, 161-166.

Meteoroloji Genel Müdürlüğü (MGM) 2020a. Retrieved in March, 1, 2020 from http://kuraklikizle.mgm.gov.tr/

Meteoroloji Genel Müdürlüğ̈̈ (MGM) 2020b. Retrieved in March, 1, 2020 from https://www.mgm.gov.tr/veridegerlendirme/kuraklik-analizi.aspx?d=yontemsinif\#sfB

Mishra, K.A. \& Singh, P.V. 2010. A review of drought concepts. Journal of Hydrology, volume 391, 202-216.

Mohammed, R. \& Scholz, M. 2017. Impact of evapotranpiration formulations at various elevations on the reconnaissance drought index. Water Resources Management 31: 531-548.

Özfidaner, M., Şapolyo, D. \& Topaloğlu, F. 2018. Seyhan havzası akım verilerinin hidrolojik kuraklık analizi. Toprak Su Dergisi 7 (1): (57-64).

Pashiardis, S. \& Michaelides, S. 2008. Implementation of the standardized precipitation index (SPI) and the reconnaissance drought index (RDI) for regional drought assessment: A case study for Cyprus. European Water Publications 23/24:57-65.

Riebsame, W.E., Changnon, S.A. \& Karl, T.R. 1991. Drought and natural resource management in the United States: impacts and implications of the 1987-1989 drought. Westview Press, Boulder, CO, p. 174.

Sırdaş, S. \& Şen, Z. 2003. Meteorolojik kuraklık modellemesi ve Türkiye uygulaması, İTÜ Mühendislik Dergisi, Cilt:2, Say1:2, 95-103.

Thom, H.C.S. 1958a. A note on gamma distribution, Monthly Weather Review 86(4): 117-122.

Thom, H.C.S. 1966b. Some methods of climatological analysis, W.M.O. Technical Note, No 81, Geneva.

Thornthwaite, C.W. 1948. An approach toward a rational classification of climate. Geographical Review, 38 (1), $55 \mathrm{e} 94$.

Topçu, E. 2018. Doğu Akdeniz, Seyhan, Ceyhan ve Asi Havzalarında Farklı Yöntemler Kullanılarak Kuraklık Analizi, Çukurova Üniversitesi, Fen Bilimleri Enstitüsü, Doktora Tezi, 313 sf, Adana.

Tsakiris, G. \& Vangelis, H. 2005. Establishing a drought index incorporating evapotranpiration. European Water Publications 9/10:3-11.

Türkeş, M., Sümer, U.M. \& Çetiner, G. 2000. Küresel iklim değişikliği ve olası etkileri, Çevre Bakanlı̆̆ı, Birleşmiş Milletler İklim Değişikliği Çerçeve Sözleşmesi Seminer Notları, 7-24, ÇKÖK Gn. Md., Ankara.

Uzunkol, M. \& Kızılelma, Y. 2016. Ceyhan Havzası'nın kuraklık durumu ve eğilimlerinin belirlenmesi. The Journal of Academic Social Science 4(29):503-519.

Vangelis, H., Tigkas, D. \& Tsakiris, G. 2013. The effect of pet method on reconnaissance drought index (RDI) calculation. Journal of Arid Environments 88: 130-140.

Wilhite. D.A. \& Glantz, M.H. 1985. Understanding the drought phenomenon: the role of definitions. Water Int. $10,111-120$.

World Meteorological Organization Bulletin (WMOB) 1999. Volume 48, No 3.

World Meteorological Organization (WMO) 2012. Standardized precipitation index user guide. WMO-No. 1090. $24 \mathrm{~s}$.

Yılmaz, M. 2017. Konya Kapalı Havzası'nın TMPA uydu kaynaklı yağış verileri ile kuraklık analizi, Journal of the Faculty of Engineering and Architecture of Gazi University 32:2, 541-549.

Yoo, H.K. \& Boyd, E.C. 1994. Hydrology and water supply for pond aquaculture. Springer US, 483s. 
Yürekli, K., Ünlükara, A. \& Yıldırım, M. 2010. Farklı yaklaşımlarla Karaman ilinin kuraklık analizi. Tarım Bilimleri Araştırma Dergisi 3(1):19-23.

Zarch, A.A.M., Malekinezhad, H., Mobin, H.M., Dastorani, T.M. \& Kousari, R.M. 2011. Drought monitoring by reconnaissance drought index (RDI) in Iran. Water Resources Management 25: 3485-3504.

Zarch, A.A.M., Sivakumar, B. \& Sharma, A. 2015. Droughts in a warming climate: A global assessment of Standardized precipitation index (SPI) and Reconnaissance drought index (RDI), Journal of Hydrology 526:183-195.

Zehtabian, G., Karimi, K., Fard, N.N.S., Mirdashtvan, M. \& Khosravi, H. 2013. Comparability analysis of the SPI and RDI meteorological drought indices in South Khorasan province Iran, International Journal of Advanced Biological and Biomedical Research, Volume 1, Issue 9:981-992. 